mgr inż. Urszula Garlińska ${ }^{1}$

mgr inż. Paweł Michalak ${ }^{1}$

mgr inż. Tomasz Popielarczyk ${ }^{1}$

Przyjęty/Accepted/Принята: 10.02.2015;

Zrecenzowany/Reviewed/Рецензирована: 28.05.2015;

Opublikowany/Published/Опубликована: 30.09.2015;

\title{
Szacowanie możliwości utraty nośności konstrukcji budowlanej w warunkach pożaru ${ }^{2}$
}

\author{
Assessment of the Potential Loss of a Building Load Bearing Capacity \\ as a Consequence of a Fire
}

\author{
Оценка вероятности потери грузоподъёмности \\ строительной конструкции в условиях пожара
}

\begin{abstract}
A B S T R A K T
Cel: Celem artykułu jest przedstawienie modelu szacującego możliwość utraty nośności przez konstrukcję budowlaną na skutek pożaru. Metody: Model szacujący możliwość utraty nośności przez konstrukcję budowlaną na skutek pożaru jest częścią narzędzia inżynierskiego, które służy do wspomagania decyzji i jest przeznaczone dla dowódców podczas działań ratowniczo-gaśniczych jednostek Państwowej Straży Pożarnej w obiektach budowlanych. Mała ilość badań pożarowych obiektów budowlanych przeprowadzanych w dużej skali oraz niewiele przypadków zawalenia się konstrukcji w pożarach rzeczywistych uniemożliwia wykorzystanie doświadczeń w tym zakresie dla projektowanego modelu. Stąd też na potrzeby opracowania modelu dokonano analizy aktów prawnych, w których zawarte są szczegółowe wymagania dotyczące nośności. Wytypowano również subiektywne symptomy utraty nośności oceniane przez dowódcę akcji ratowniczo-gaśniczej. W dalszym etapie prac nad modelem należy przeprowadzić wywiady i ankiety wśród dowódców, którzy posiadają odpowiednie doświadczenie i mogą określić pewne oznaki, które towarzyszą zawaleniu się konstrukcji budowlanej podczas pożaru. Wyniki: Opracowano model szacujący możliwość utraty nośności przez konstrukcję budowlaną na skutek pożaru, który obejmuje budynki charakteryzowane kategorią zagrożenia ludzi (ZL), produkcyjne i magazynowe (PM) oraz obiekty budowlane, dla których nie określono wymagań prawnych w zakresie wytrzymałości konstrukcji lub zostały one zniesione przed 1994 r. Po przeprowadzeniu analizy literaturowej, na obecnym etapie prac, wytypowano 6 głównych oznak utraty nośności przez konstrukcję budowlaną na skutek pożaru, których ocena możliwa jest przy odpowiednio przeprowadzonym rozpoznaniu podczas akcji ratowniczo-gaśniczej. Przeprowadzenie wywiadów i ankiet umożliwi porównanie wytypowanych oznak utraty nośności z rzeczywistymi symptomami określonymi przez dowódców. Wnioski: Zaproponowany model może stanowić ważną pomoc dla dowódców podczas akcji ratowniczo-gaśniczych. Niezbędne jest jednak wykorzystanie doświadczenia dowódców z wieloletnim stażem, do optymalnego określania ryzyka utraty nośności konstrukcji.
\end{abstract}

Słowa kluczowe: utrata nośności konstrukcji budowlanej, wspieranie decyzji dowódcy, działania ratowniczo-gaśnicze, bezpieczeństwo pożarowe

Typ artykułu: doniesienie wstępne

\section{ABSTRACT}

Aim: The purpose of this article is to present a model to predict the potential loss of a building load bearing capacity as a consequence of a fire.

Methods: The proposed model is part of an engineer's toolbox, used for decision making purposes and intended for use by commanders of the Polish State Fire Service (PSFS) during firefighting and rescue operations in buildings. There is a limited number of full scale studies performed on buildings exposed to fire activity and infrequent incidents involving the collapse of buildings as a result of fires, making it difficult to harness practical experience in this area for the development of a model. For this reason the model is based on an analysis of national statutes, which contain specific requirements appertaining to load bearing capacities. The authors also utilized subjective assessments of deterioration to the building construction load bearing capacity, provided by commanders responsible for fire-rescue operations.

\footnotetext{
Centrum Naukowo-Badawcze Ochrony Przeciwpożarowej - Państwowy Instytut Badawczy; / Scientific and Research Centre for Fire Protection - National Research Institute, Poland; tpopielarczyk@cnbop.pl;

2 Autorzy wnieśli jednakowy wkład merytoryczny w powstanie artykułu / The authors contributed equally to this article;
} 
In the subsequent phase of model development, it is appropriate to conduct interviews and questionnaires among commanders, who have appropriate experience and can identify certain signs, which accompany the collapse of building structures during fire incidents. Results: A model was designed, to determine the potential loss of a building's load-carrying capacity under fire conditions. The model covers three types of the buildings: one where a hazard to humans is created (ZL), the second incorporates buildings used for production and storage (PM) and third concerns other buildings, for which there are no statutory requirements for structural strength or buildings built before 1994. After an analysis of literature, the authors selected 6 key indicators, which point to a potential loss of load bearing capacity during fire incidents. An evaluation of these indicators is possible by Commanders during fire incident operations. Interviews and questionnaires will provide information for comparison between selected indicators and actual symptoms identified by commanders. Conclusions: The proposed model enables the assessment of the potential loss of a building load bearing capacity under fire conditions and can provide important support for commanders during fire and rescue operations. However, it is necessary to use the experience of commanders, to optimise decisions about any deterioration to building load bearing capacity during fire incidents.

Keywords: loss of the building load carrying capacity, support the commander's decision, fire and rescue operations, fire safety Type of article: short scientific report

\section{АННОТАЦИЯ}

Цель: Цель данной статьи заключается в представлении модели, которая позволяет оценить вероятность потери грузоподъёмности строительной конструкции в результате пожара.

Методы: Модель, которая оценивает вероятность потери грузоподъёмности строительной конструкции в результате пожара, является элементом инженерного метода, который используется для поддержки решений и предназначен для руководителей спасательно-гасящих действий подразделений Государственной Пожарной Службой Польши, проводимых на строительных объектах. Небольшое количество полномасштабных исследований пожаров строительных объектов и небольшое число случаев полного разрушения зданий при реальных пожарах делает невозможным использование практического опыта в этой области для предложенной модели. Поэтому с этой целью был совершен анализ правовых актов, в которых содержатся подробные требования относительно грузоподъёмности. Были выбраны также субъективные признаки потери грузоподъёмности, оцениваемые руководителями спасательно-гасящих действий. На следующем этапе работ над моделью следует провести интервью и опросы среди руководителей спасательно-гасящих действий, у которых есть соответственный опыт и которые могут указать некоторые признаки, сопровождающие разрушение строительной конструкции во время пожара. Результаты: Была разработана модель, которая оценивает вероятность потери грузоподъёмности строительной конструкции в результате пожара, охватывающего здания категории ZL, которые представляют угрозу для людей, производственные здания и склады (РM), а также строительные объекты, для которых не определены правовые требования относительно их грузоподъёмности или они были отклонены до 1994 года. После проведения анализа литературы на данном этапе работ выбраны 6 главных симптомов потери грузоподъёмности строительной конструкции в результате пожара, оценка которых возможна только при соответственно проведённом распознавании во время спасательно-гасящих действий. Интервью и опросы позволят сравнить выбранные симптомы потери грузоподъёмности с реальными симптомами, определенными руководителями действий.

Выводы: Предложенная модель может помочь руководителям спасательно-гасящих действий. Для оптимального определения риска потери грузоподъёмности необходимо, однако, использовать также опыт руководителей действий с многолетним стажем.

Ключевые слова: потеря грузоподъёмности строительной конструкции, поддержка принятия решений руководителем, спасательно-гасящие действия, пожарная безопасность

Вид статьи: предварительный отчёт

\section{Wprowadzenie}

Kierowanie akcją gaśniczą jest procesem złożonym obejmującym zarówno planowanie, jak i organizowanie, nadzorowanie i koordynowanie działań. Aby osiągnąć pożądane rezultaty, dowódca akcji ratowniczo-gaśniczej powinien mieć na uwadze wiele różnorodnych czynników oraz posiadać umiejętność przewidywania ich zmienności oraz ryzyka dla skutków ich wystąpienia. Z uwagi na wysokie prawdopodobieństwo znacznych strat oraz konieczność przeprowadzenia szybkich działań, za szczególnie problematyczne uważa się dowodzenie akcją ratowniczo-gaśniczą w obiektach budowlanych.

Budynki wraz z zainstalowanymi urządzeniami powinny być zaprojektowane i wykonane w sposób zapewniający w razie pożaru m.in. zachowanie nośności konstrukcji minimum przez czas wynikający z rozporządzenia Ministra Infrastruktury [1] lub poprzedzającego go rozporządzenia Ministra Gospodarki Przestrzennej i Budownictwa [2]. W niniejszym artykule przedstawiono koncepcję modelu szacowania możliwości utraty nośności przez konstrukcję budowlaną na skutek pożaru. Omówiony model uwzględnia wymagania krajowych przepisów w zakresie ochrony przeciwpożarowej obiektów budowlanych oraz ocenę subiektywnych symptomów świadczących o możliwości utraty nośności przez konstrukcję budowlaną. Jako końcowa zostaje zwrócona, w pięciostopniowej skali, wartość określająca prawdopodobieństwo utraty przez konstrukcję nośności w warunkach pożaru. W kolejnym etapie badań planuje się określenie subiektywnych oznak wraz z przypisaniem im wag do szacowania końcowej wartości ryzyka.

\section{Metody}

Zespół autorów zaproponował model szacujący możliwość utraty nośności przez konstrukcję budowlaną na skutek pożaru, który spełnia wyznaczone kryteria. Nośność, czyli „zdolność do przejęcia określonych oddziaływań” [3], odniesiono do całej konstrukcji budowlanej. Poszczególne elementy konstrukcji mogą przenosić pomiędzy sobą obciążenia, w sytuacji, gdy jeden element utraci nośność, jego funkcje mogą przejąć sąsiednie elementy, dzięki czemu 
cała konstrukcja zachowuje właściwości nośne. Przyjęto, że właściwości nośne związane są z obciążeniami normalnymi, a nie funkcjonalnymi (trudnymi do przewidzenia w trakcie prowadzenia działań ratowniczo-gaśniczych), oraz należy je odnosić do całej konstrukcji budowlanej, a nie jej poszczególnych elementów. W związku z tym, przyjętą utratę nośności konstrukcji budowlanej należy traktować jako zawalenie obiektu budowlanego, a co za tym idzie zaproponowanej koncepcji modelu nie można odnosić do oceny popożarowej obiektu budowlanego.

\section{Wyniki}

Z uwagi na niewielką ilość badań pożarowych obiektów budowlanych przeprowadzanych w dużej skali oraz brak wyczerpujących danych dotyczących zawalenia się konstrukcji w sytuacji pożarowej, w pierwszej kolejności przeanalizowano wymagania prawne stawiane obiektom budowlanym w zakresie ochrony przeciwpożarowej. Proponowaną koncepcję oparto na wymaganiach prawnych stawianych obiektom budowlanym oraz subiektywnej ocenie symptomów dokonywanej przez dowódcę akcji ratowniczo-gaśniczej. Podstawowym dokumentem regulującym krajowe wymagania dotyczące odporności pożarowej konstrukcji nośnej obiektów pożarowych jest wprowadzone w 2002 roku Rozporządzenie Ministra Infrastruktury w sprawie warunków technicznych jakim powinny odpowiadać budynki i ich usytuowanie [1], które zastąpiło obowiązujące wcześniej Rozporządzenie Ministra Gospodarki Przestrzennej i Budownictwa [2]. W wyżej wymienionych dokumentach zostały wskazane wymagane klasy odporności ogniowej (i przypisane im minimalne czasy) dla konstrukcji nośnej obiektów budowlanych w zależności od ich przeznaczenia, wysokości i (w przypadku obiektów przemysłowych i magazynowych) maksymalnej gęstości obciążenia ogniowego strefy pożarowej. W oparciu o nie zostaje wyznaczony projektowy czas wytrzymałości konstrukcji nośnej. Zwraca się szczególną uwagę na to, iż oceny zgodności elementów konstrukcji z wymaganiami (w szczególności w zakresie kryterium nośności - R) można dokonać na kilka sposobów, jak również, że zgodnie z obowiązującym prawem warunki uznaje się za spełnione, jeżeli konstrukcja ta odpowiada polskim normom dotyczącym projektowania i obliczania konstrukcji [4].

Diagram czynności realizowanych przez model zobrazowano na rycinie 1 .

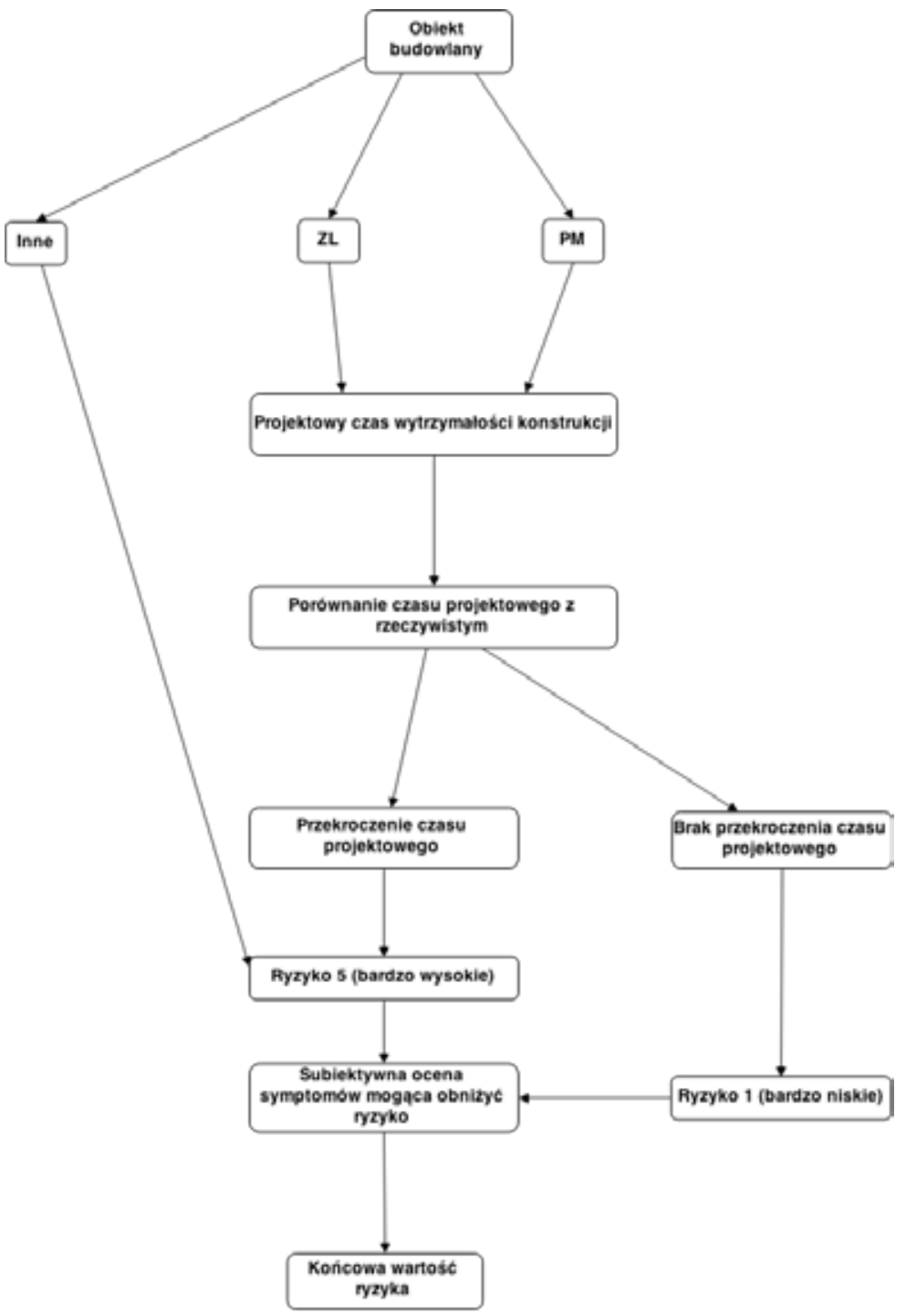

Ryc. 1. Diagram czynności modelu szacującego możliwość utraty nośności przez konstrukcję budowlaną na skutek pożaru Źródło: Opracowanie własne. 


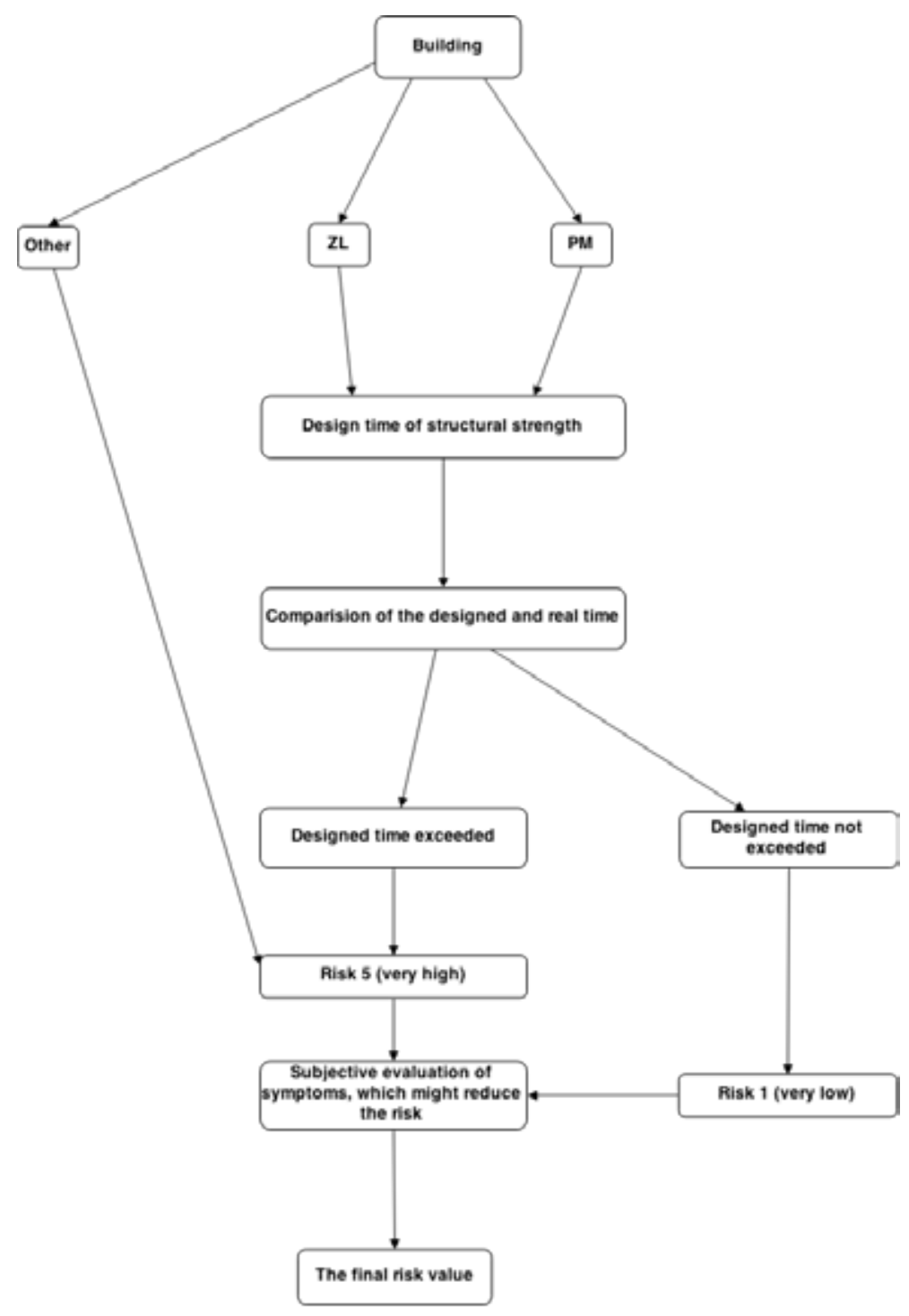

Fig. 1. Activity diagram for modelling of the possible loss of building's load-carrying capacity during a fire Source: Own elaboration.

\subsection{Obiekty magazynowe i przemysłowe}

Dla obiektów magazynowych i przemysłowych (budynki klasyfikowane jako PM) wymagania odnośnie minimalnych czasów odporności ogniowej konstrukcji nośnej nie zmieniły się wraz ze zmianą przepisów, a ich wartości zostały przedstawione $\mathrm{w}$ tabeli 1 . Zmiany nie zaszły również w nazewnictwie wysokości budynków, zgodnie z którym wyróżnia się: budynki niskie (do $12 \mathrm{~m}$ włącznie nad poziomem terenu lub mieszkalne o wysokości do 4 kondygnacji nadziemnych włącznie), średniowysokie (ponad $12 \mathrm{~m}$ do $25 \mathrm{~m}$ włącznie nad poziomem terenu lub mieszkalne o wysokości ponad 4 do 9 kondygnacji nadziemnych włącznie), wysokie (ponad $25 \mathrm{~m}$ do $55 \mathrm{~m}$ włącznie nad poziomem terenu lub mieszkalne o wysokości ponad 9 do 18 kondygnacji nadziemnych włącznie) i wysokościowe (powyżej $55 \mathrm{~m}$ nad poziomem terenu). 
Tabela 1. Wymagane minimalne czasy wytrzymałości konstrukcji nośnej dla budynków kategorii PM [min]

Table 1. Required minimum time of structural strength for the production and storage buildings PM [min]

\begin{tabular}{|c|c|c|c|c|c|}
\hline \multirow{2}{*}{$\begin{array}{c}\text { Maksymalna gęstość obciążenia } \\
\text { ogniowego strefy pożarowej } \\
\text { w budynku } Q\left[\mathrm{MJ} / \mathrm{m}^{2}\right] / \\
\text { Maximum fire load density of fire } \\
\text { zone in the building } Q\left[\mathrm{MJ} / \mathrm{m}^{2}\right]\end{array}$} & \multirow{2}{*}{$\begin{array}{c}\text { Budynek o jednej } \\
\text { kondygnacji nadziemnej (bez } \\
\text { ograniczenia wysokości) / } \\
\text { Single storey building (no } \\
\text { height limit) }\end{array}$} & \multicolumn{4}{|c|}{$\begin{array}{c}\text { Budynek wielokondygnacyjny / } \\
\text { Multi-storey building }\end{array}$} \\
\hline & & $\begin{array}{l}\text { Niski / } \\
\text { Low-rise } \\
(\mathrm{N})\end{array}$ & $\begin{array}{c}\text { Średniowysoki / } \\
\text { Mid-rise } \\
(\mathrm{SW})\end{array}$ & $\begin{array}{c}\text { Wysoki / } \\
\text { High-rise } \\
(\mathrm{W})\end{array}$ & $\begin{array}{l}\text { Wysokościowy/ } \\
\text { Skyscraper } \\
\text { (WW) }\end{array}$ \\
\hline $\mathrm{Q} \leq 500$ & $\begin{array}{c}\text { Brak wymagań } \\
\text { / No requirements }\end{array}$ & 30 & 60 & 120 & 120 \\
\hline $500<\mathrm{Q} \leq 1000$ & 30 & 30 & 60 & 120 & 120 \\
\hline $1000<\mathrm{Q} \leq 2000$ & 60 & 60 & 60 & 120 & 120 \\
\hline $2000<\mathrm{Q} \leq 4000$ & 120 & 120 & 120 & $>$ & $\infty$ \\
\hline $\mathrm{Q}>4000$ & 140 & 240 & 240 & & \\
\hline
\end{tabular}

Źródło: Opracowanie własne na podstawie [1-2].

Source: Own elaboration based on [1-2].

\subsection{Budynki ZL}

Nieco bardziej skomplikowane staje się jednak określenie projektowego minimalnego czasu wytrzymałości konstrukcji nośnej dla budynków kategorii ZL (mieszkalne, zamieszkania zbiorowego i użyteczności publicznej), ponieważ zmianie uległy nie tylko wymagania co do minimalnego czasu, ale również sam podział na kategorie ZL. Różnice zostały zobrazowane w tabeli 2.

Tabela 2. Podział budynków ze względu na kategorię zagrożenia ZL

Table 2. Types of building ZL - human hazard category

\begin{tabular}{|c|c|c|}
\hline ZL & $\begin{array}{l}\text { Przed } 2002 \text { rokiem } \\
\text { Before } 2002\end{array}$ & $\begin{array}{l}\text { Od } 2002 \text { roku } \\
\text { After } 2002\end{array}$ \\
\hline ZL I & $\begin{array}{l}\text { budynki użyteczności publicznej lub ich części, } \\
\text { w których mogą przebywać ludzie w grupach ponad } \\
50 \text { osób / } \\
\text { public buildings or their parts, in which people can } \\
\text { stay in groups of more than } 50 \text { people }\end{array}$ & $\begin{array}{l}\text { budynki zawierające pomieszczenia przeznaczone do } \\
\text { jednoczesnego przebywania ponad } 50 \text { osób nie będących ich } \\
\text { stałymi użytkownikami, a nie przeznaczone przede wszystkim } \\
\text { do użytku ludzi o ograniczonej zdolności poruszania się / } \\
\text { buildings containing rooms for the simultaneous presence } \\
\text { of more than } 50 \text { people who are not their regular users, not } \\
\text { primarily intended for use by people with limited mobility }\end{array}$ \\
\hline ZL II & $\begin{array}{c}\text { budynki lub ich części przeznaczone do użytku ludzi } \\
\text { o ograniczonej zdolności poruszania się / } \\
\text { buildings or parts intended for use by people with } \\
\text { limited mobility }\end{array}$ & $\begin{array}{l}\text { budynki przeznaczone przede wszystkim do użytku ludzi } \\
\text { o ograniczonej zdolności poruszania się, takie jak szpitale, } \\
\text { żłobki, przedszkola, domy dla osób starszych / } \\
\text { buildings intended for use by people with limited mobility, such } \\
\text { as hospitals, nurseries, kindergartens, homes for the elderly }\end{array}$ \\
\hline ZL III & $\begin{array}{l}\text { szkoły, budynki biurowe, domy studenckie, internaty, } \\
\text { hotele, ośrodki zdrowia, otwarte przychodnie lekarskie, } \\
\text { sanatoria, lokale handlowo-usługowe, w których } \\
\text { może przebywać do } 50 \text { osób, koszary, pomieszczenia } \\
\text { Elektronicznej Techniki Obliczeniowej (ETO), zakłady } \\
\text { karne i inne podobne / } \\
\text { schools, office buildings, dormitories, boarding schools, } \\
\text { hotels, health centers, open medical clinics, sanatoriums, } \\
\text { commercial and service premises, which can hold up to } \\
50 \text { people, barracks, Electronic Computing Technology } \\
\text { (ETO) rooms, prisons and other similar }\end{array}$ & $\begin{array}{c}\text { budynki użyteczności publicznej, niezakwalifikowane do } \\
\text { ZL I i ZL II / } \\
\text { public buildings, not categorized as ZLI and ZL II }\end{array}$ \\
\hline ZL IV & $\begin{array}{l}\text { budynki mieszkalne / } \\
\text { residential buildings }\end{array}$ & $\begin{array}{l}\text { budynki mieszkalne / } \\
\text { residential buildings }\end{array}$ \\
\hline ZL V & $\begin{array}{l}\text { archiwa, muzea i biblioteki / } \\
\text { archives, museums and libraries }\end{array}$ & $\begin{array}{l}\text { budynki zamieszkania zbiorowego, niezakwalifikowane do } \\
\text { ZL I i ZL II / } \\
\text { collective residential buildings, not categorised as ZLI and ZL II }\end{array}$ \\
\hline
\end{tabular}

Źródło: Opracowanie własne na podstawie [1-2].

Source: Own elaboration based on [1-2]. 
W odniesieniu do obiektów zakwalifikowanych jako ZL wraz ze zmianą przepisów zaszły również zmiany odnośnie minimalnych czasów odporności pożarowej konstrukcji nośnej, które przed 2002 rokiem ustalone były na poziomie: - minimum 120 min dla liczących powyżej 2 kondygnacji ZL I, ZL II i ZL V, wysokie i wysokościowe ZL III, wysokościowe ZL IV;

- minimum 60 min dla dwukondygnacyjnych ZL I, ZL II i ZL V, powyżej 2 kondygnacji niskie i średniowysokie ZL III, powyżej 3 kondygnacji niskie, średniowysokie i wysokie ZL IV;

- minimum 30 min dla jednokondygnacyjnych ZL II, do 2 kondygnacji ZL III i trzykondygnacyjne ZL IV.

Nie została przewidziana minimalna odporność pożarowa konstrukcji nośnej dla budynków kategorii ZL wynosząca 240 minut, natomiast dla budynków jednokondygnacyjnych z elementów nierozprzestrzeniających ognia ZL I i ZL V oraz do 2 kondygnacji ZL IV nie przedstawiono kryteriów.

Zdecydowanie zaostrzono wymagania w 2002 roku, ustalając:

- minimum 240 min dla budynków wysokościowych z wyłączeniem ZL IV;

- minimum 120 min dla wszystkich budynków wysokich, wysokościowych ZL IV, średniowysokich z wyłączeniem ZL IV i niskich ZL I i ZL II;

- minimum 60 min dla niskich ZL III i ZL V oraz średniowysokich ZL IV;

- minimum 30 min dla niskich ZL IV.

Dodatkowo, gdy obiekt jest wyposażony w stałe urządzenia gaśnicze, dopuszcza się obniżenie minimalnego czasu odporności pożarowej konstrukcji nośnej o połowę. Zakłada się więc, że w takim przypadku czas ten zostanie obniżony. Przeprowadzona analiza pozawala na określenie projektowego czasu wytrzymałości konstrukcji.

\subsection{Inne obiekty}

W przypadku obiektów nie zakwalifikowanych do kategorii ZL ani PM przyjmuje się, że z racji braku wymagań prawnych dotyczących konstrukcji nośnej, ryzyko zawalenia takiego na skutek pożaru jest bardzo wysokie.

\section{Działanie modelu}

Po wyznaczeniu minimalnego projektowego czasu wytrzymałości konstrukcji, projektowe obciążenie termiczne zostaje porównane z rzeczywistym. Szczegółowe informacje dotyczące rzeczywistego przebiegu pożaru dostarczone zostają od innego modułu będącego elementem narzędzia do wspomagania decyzji, przeznaczonego dla dowódców podczas działań ratowniczo-gaśniczych PSP w obiektach budowlanych. Obciążenie termiczne projektowe (OTP), czyli scałkowana wartość temperatury w zależności od czasu na jaki zaprojektowana jest dana konstrukcja nośna obiektu budowlanego, obliczana jest w następujący sposób:

$\Theta_{\mathrm{p}}(\mathrm{t})=20+345 \cdot \log _{10}(8 \cdot \mathrm{t}+1)-$ krzywa standardowa przebiegu pożaru [3]

$\mathrm{t}_{0}$ - czas początkowy pożaru

$t_{p}$ - czas wyznaczonej minimalnej odporności konstrukcji nośnej

$$
O T P=\int_{t_{0}}^{t_{p}} \Theta_{p}(t) d t
$$

OTR - obciążenie termiczne rzeczywiste

$\Theta_{r}(t)$ - krzywa temperaturowa zgodnie z rzeczywistym rozkładem temperatury

$\mathrm{t}_{0}$ - czas początkowy pożaru

$\mathrm{t}_{\mathrm{r}}$ - czas rzeczywisty (czas obliczeń)

$$
O T R=\int_{t_{0}}^{t_{r}} \Theta_{r}(t) d t
$$

W celu sprawdzenia, czy nastąpiło przekroczenie czasu, należy przyrównać otrzymane wartości. Gdy OTR $\geq$ OTP występuje przekroczenie czasu projektowego. W przeciwnym razie, gdy OTR $<$ OTP - przekroczenie czasu projektowego nie występuje.

Dla obiektów nieobjętych uregulowaniami prawnymi w zakresie wymagań klas odporności ogniowej przyjmuje się ryzyko bardzo wysokie, tak samo jak dla budynków, dla których rzeczywista energia cieplna przekroczyła wymagania projektowe. Gdy przekroczenie czasu projektowego nie wystąpiło - ryzyko klasyfikuje się jako bardzo niskie (wartość 1 w pięciostopniowej skali ryzyka). Przewidziano możliwość obniżenia ryzyka bardzo wysokiego (bądź podwyższenia ryzyka bardzo niskiego) poprzez przeprowadzenie subiektywnej oceny właściwości pożaru. Po przeprowadzeniu analizy literaturowej [5-7], na obecnym etapie prac, wytypowano 6 głównych oznak utraty nośności przez konstrukcję budowlaną na skutek pożaru, których ocena możliwa jest przy odpowiednio przeprowadzonym rozpoznaniu podczas akcji ratowniczo-gaśniczej. Zaliczono do nich:

- wystąpienie eksplozji (wybuchów);

- pęknięcia ścian;

- wyboczenia elementów konstrukcji;

- przechylenie konstrukcji obiektu budowlanego;

- nietypowe odgłosy (trzaski, skrzypienie itp.);

- wydobywanie się wody lub dymu ze spoin.

Dla każdej oznaki dowódca akcji ma możliwość zadeklarowania jednego ze stanów:

- TAK;

- NIE;

- BD (brak danych).

Automatycznie dla każdego symptomu zakłada się przypisanie wartości „brak danych”, która do obliczeń końcowej wartości ryzyka ma wartość zerową - nie wpływa na ostateczne ryzyko. Wybór stanu „nie występuje” obniża wartość ryzyka o zadaną wartość (lub do wartości minimalnej 1), natomiast stan „występuje” podwyższa wartość ryzyka końcowego o zadaną wartość (lub do wartości maksymalnej wynoszącej 5). Przyjęcie takiego rozwiązania daje możliwość otrzymania końcowych wartości ryzyka w przedziale od 1 do 5 z krokiem 0,5, oznaczając odpowiednio:

- ryzyko bardzo niskie - gdy wartość końcowa ryzyka wynosi 1,0;

- ryzyko niskie - gdy wartość końcowa ryzyka wynosi 1,5 lub 2,0;

- ryzyko średnie - gdy wartość końcowa ryzyka wynosi 2,5 lub 3,0;

- ryzyko wysokie - gdy wartość końcowa ryzyka wynosi 3,5 lub 4,0; 
- ryzyko bardzo wysokie - gdy wartość końcowa ryzyka wynosi 4,5 lub 5,0.

W kolejnych etapach prac planowane jest przeprowadzenie weryfikacji symptomów i podjęcie próby przypisania im odpowiednich wag do obliczeń wartości końcowego ryzyka.

\section{Dyskusja nad metodami i wynikami}

Pożar jest złożonym procesem, zależnym w głównej mierze od materiału palnego oraz dostępu do utleniacza. Biorąc pod uwagę maksymalną gęstość obciążenia ogniowego dla budynków kategorii PM oraz podziału ze względu na kategorię zagrożenia ZL, przez ustawodawcę zostały określone minimalne czasy odporności pożarowej konstrukcji nośnej. Opracowując opisany model założono, że obiekty budowlane niespełniające opisanych wymagań nie występują. Czasy odporności pożarowej zostały przyjęte jako podstawa do wyznaczenia algorytmu określającego prawdopodobieństwo utraty nośności przez konstrukcję. Ponieważ jednak w warunkach pożaru konstrukcja budynku poddawana jest licznym oddziaływaniom termicznym i mechanicznym, które powodują pojawienie się widocznych symptomów, w metodyce zostały wprowadzone dodatkowe współczynniki korygujące określone wcześniej prawdopodobieństwo. Końcowy algorytm opiera się zatem na określonych w rozporządzeniu czasach odporności pożarowej oraz subiektywnej ocenie opartej na weryfikacji występujących symptomów utraty nośności przez konstrukcję na skutek pożaru. Taki model może być z powodzeniem wykorzystywany jako element narzędzia dedykowanego wsparciu decyzji dowódców działań ratowniczo-gaśniczym PSP w obiektach budowlanych.

\section{Podsumowanie}

Powstały model ma być w szczególności wsparciem dla dowódców podczas akcji ratowniczo-gaśniczych jako element rozbudowanego narzędzia. Opracowany algorytm nie zastąpi dowódcy, jednak w znaczącym stopniu może ułatwić podjęcie decyzji w sytuacji ograniczonego czasu i danych wejściowych. Opracowanie oparte na minimalnych czasach określonych w aktach prawnych oraz na ocenie symptomów zawiera pomocne informacje zdecydowanie ułatwiające podjęcie odpowiednich decyzji, które mogą mieć wpływ na dalszy przebieg akcji ratowniczo-gaśniczej oraz jej rezultat, w tym również na zdrowie i życie ratowników i użytkowników obiektów.

Artykuł został opracowany w ramach projektu nr DOBR/0010/R/ID1/2013/03 pt. „Nowoczesne narzędzia inżynierskie do wspomagania decyzji przeznaczone dla dowódców podczas działań ratowniczo-gaśniczych PSP $\mathrm{w}$ obiektach budowlanych" finansowanego przez Narodowe Centrum Badań i Rozwoju.

\section{Skróty}

OTP - obciążenie termiczne projektowe

OTR - obciążenie termiczne rzeczywiste

PM - budynki produkcyjne i magazynowe

ZL - kategorie zagrożenia ludzi

\section{Literatura}

[1] Rozporządzenie Ministra Infrastruktury z dnia 12 kwietnia 2002 w sprawie warunków technicznych jakim powinny odpowiadać budynki i ich usytuowanie (Dz. U. Nr 75, poz. 690).

[2] Rozporządzenie Ministra Gospodarki Przestrzennej i Budownictwa z dnia 14 grudnia 1994 roku w sprawie warunków technicznych, jakim powinny odpowiadać budynki i ich usytuowanie (Dz. U. $1995 \mathrm{Nr}$ 10, poz. 46).

[3] PN-EN 1991-1-2:2006 Eurokod 1: Oddziaływania na konstrukcje - Część 1-2: Oddziaływania ogólne - Oddziaływania na konstrukcje w warunkach pożaru.

[4] Król P., Ocena odporności ogniowej stropów na belkach stalowych, BiTP, Vol. 35 Issue 3, 2014, pp. 73-79.

[5] Poremba J., Building Collapse: Learn the Warning Signs [dok. elektr.], http://www.firerescuel.com/firefighter-safety/articles/458061-Building-Collapse-Learn-the-Warning-Signs/ [dostęp: 29.01.2015].

[6] Robertson H., Establishing Collapse Zones at Structure Fires [dok. elektr.], http://www.firefighternation.com/article/special-operations/establishing-collapse-zones-structure-fires [dostęp: 29.01.2015].

[7] Brennan T., The signs of impending building collapse [dok. elektr.], http://www.fireengineering.com/articles/print/ volume-153/issue-7/departments/random-thoughts/ the-signs-of-impending-building-collapse.html [dostęp: 29.01.2015].

mgr inż. Urszula Garlińska - absolwentka Wydziału Inżynierii Bezpieczeństwa Cywilnego i Wydziału Inżynierii Bezpieczeństwa Pożarowego Szkoły Głównej Służby Pożarniczej w Warszawie oraz studiów podyplomowych na Politechnice Warszawskiej i Wyższej Szkoły Informatyki i Zarządzania w Rzeszowie. Od 2013 pracownik Zespołu Laboratoriów Sygnalizacji Alarmu Pożaru i Automatyki Pożarniczej CNBOP-PIB, w którym zajmuje się badaniami kwalifikacyjnymi elementów dźwiękowych systemów ostrzegawczych.

mgr inż. Paweł Michalak - absolwent Wydziału Elektrycznego Politechniki Warszawskiej oraz Podyplomowych Studiów Zarządzania Projektami Szkoły Głównej Handlowej w Warszawie. Od 2013 roku pracownik Zespołu Laboratoriów Sygnalizacji Alarmu Pożaru i Automatyki Pożarniczej, w którym zajmuje się badaniami kwalifikacyjnymi systemów transmisji alarmów pożarowych i sygnałów uszkodzeniowych oraz opraw oświetleniowych do oświetlenia awaryjnego. 
DOI:10.12845/bitp.39.3.2015.5

mgr inż. Tomasz Popielarczyk - absolwent Wydziału Inżynierii Bezpieczeństwa Pożarowego Szkoły Głównej Służby Pożarniczej w Warszawie. Od początku swojej pracy zawodowej związany z Centrum Naukowo-Badawczym Ochrony Przeciwpożarowej, jako pracownik Zespołu Laboratoriów Sygnalizacji Alarmu Pożaru i Automatyki Pożarniczej. Od 2013 r. pełni funkcję zastępcy kierownika Zespołu Laboratoriów. Zajmuje się badaniami kwalifikacyjnymi, w tym badaniami funkcjonalnymi, środowiskowymi oraz kompatybilności elektromagnetycznej, na potrzeby certyfikacji urządzeń systemów sygnalizacji pożarowej, głównie central i głośników do dźwiękowych systemów ostrzegawczych oraz systemów zasilania. Ponadto jako auditor wiodący lub techniczny dokonuje ocen zakładowej kontroli produkcji badanych wyrobów. Jest autorem publikacji na tematy związane z ochroną przeciwpożarową budynków i obiektów budowlanych. 